\title{
Implementasi Sistem Bagi Hasil Mudharabah pada Koperasi Serba Usaha Amanah Desa Bunobogu Kecamatan Bunobogu Kabupaten Buol
}

\author{
Abdul Latif \\ Abdullatif1003@gmail.com \\ Pipitriyana \\ Pipiterawan22@gmail.com
}

\begin{abstract}
ABSTRAK
Penelitian ini bertujuan untuk mengetahui sistem bagi hasil Mudharabah pada Koperasi Serba Usaha (KSU) Amanah Desa Bunobogu dengan metode Analisis Deskriptif Kualitatif. Penelitian ini menggunakan sumber data primer dan data sekunder yang berkaitan dengan sistem bagi hasil Mudharabah periode tahunan (20102014). Hasil penelitian ini menunjukkan bahwa sistem bagi hasil di laksanakan oleh Koperasi Serba Usaha (KSU) Amanah Desa Bunobogu dalam bentuk pembiayaan Mudharabah. Dengan pernyataan jaminan pada proses akadnya. Jika terjadi kelalaian yang dilakukan oleh anggota yang mengakibatkan usahanya merugi maka barang yang di buat jaminan akan disita oleh koperasi. Usaha yang didirikan anggota kebanyakan tergolong usaha kecil menengah jadi sering di temui pembukuan yang tidak jelas dan hanya membuat pembukuan anggaran yang asal-asalan. Namun demikian, tak menjadi alaasan dan menghambat pertumbuhan koperasi yang tiap tahunnya mengalami peningkatan sisa hasil usaha. Pembukuan anggaran yang tidak jelas dapat berakibat pada manipulasi laba yang di lakukan oleh anggota, dengan memperendah laba yang di peroleh dan pengaruh pada angsuran bagi hasil.
\end{abstract}

\section{Kata Kunci: Inflementasi, bagi hasil, Mudharabah.}

\begin{abstract}
This study aims to determine the system for the results of Mudharabah on Business Multipurpose Cooperative (KSU) Amanah Desa Bunobogu with Qualitative Descriptive Analysis method. This study uses primary data sources and secondary data relating to the annual revenue sharing system Mudharabah (2010-2014). The results of this study indicate that the profit sharing system is implemented by the Multipurpose Business Cooperative (KSU) Amanah Desa Bunobogu in the form of Mudharabah financing. With a guarantee statement on the process akadnya. In the event of negligence made by members who resulted in his business losing the goods made in the guarantee will be seized by the cooperative. Businesses that are established by members are mostly small and medium enterprises so often encountered bookkeeping that is not clear and just make a budget booklet at random. However, it does not become alaasan and hamper the growth of cooperatives which each year has increased the remaining results of operations. Unclear budget bookkeeping can result in member earnings manipulation, by lowering the profits earned and the effect on the revenue share installments.
\end{abstract}

Keywords: Implementation, profit sharing, Mudharabah. 


\section{A. Latar Belakang}

Koperasi mempunyai peran penting dalam tercapainya kesejahteraan bagi anggota khususnya dan masyarakat pada umumnya. Koperasi dalam kegiatannya memiliki karakter yang khas yaitu bersifat mementingkan pendidikan, perkoperasian bagi anggota dan masyarakat. Koperasi menurut undang-undang nomor 25 tahun 1992 tentang perkoperasi merupakan suatu badan usaha, sehingga koperasi tetap tunduk pada kaidah-kaidah perusahaan dan prinsip-prinsip ekonomi yang berlaku. Karena itu, koperasi harus menghasilkan keuntungan dalam mengembangkan organisasi dan usahanya. Pembangunan koperasi yang merupakan perwujudan kearah amanat konstitusi bangsa Indonesia, yaitu pada Undang-undang 1945 khususnya pasal 33 ayat 1 (1) yaitu perekonomian Indonesia di susun sebagai usaha bersama berdasarkan atas asas kekeluargaan dan koperasi adalah bangunan usaha yang sesuai dengan susunan perekonomian yang di maksud. Oleh karena itu, koperasi di harapkan memainkan peran penting dalam perekonomian Indonesia, yaitu koperasi sebagai Soko Guru perekonomian di Indonesia. ${ }^{1}$

Prinsip demokrasi ekonomi hanya dapat di implemetasikan dalam wadah koperasi yang berasaskan kekeluargaan. Secara operasional, kegiatan produksi dan konsumsi yang jika dikerjakan sendiri-sendiri tidak akan berhasil. Akan tetapi koperasi mengenal akan prinsip gotong royong dimana anggota bersama-sama memberdayakan koperasi untuk kepentingan bersama, maka melakui koperasi yang telah mendapat mandat dari anggota-anggotanya hal tersebut dapat di lakukan dengan lebih berhasil. ${ }^{2}$

Salah satu usaha koperasi syariah dalam memberdayakan masyarakat luas adalah dengan menghapus sistem bunga dan di ganti dengan sistem bagi hasil dalam usaha simpan pinjam, yang di selenggarakan oleh koperasi karena menghindari masyarakat kecil terjerat rentenir. Oleh karena itu Koperasi Serba Usaha (KSU) Amanah desa Bunobogu memakai sistem Bagi Hasil dalam melakukan usaha simpan pinjamnya.

Koperasi Serba Usaha (KSU) Amanah Desa Bunobogu telah berbadan hukum 69/518/BH/DISKOP/UKM PM/XI/2003 adalah Koperasi Serba Usaha (KSU)

\footnotetext{
${ }^{1}$ Ninik widiyanti dan Sunindhia, Koperasi dan Perekonomian Indonesia. (Jakarta: PT. Rineka Cipta. 2000) h.34

${ }^{2}$ Firdaus, Muhamad Sutanto, Agus Edhi, Perkoperasian sejarah, teori dan praktek. (Jakarta: Ghallia Indonesia;2002).H.21
} 
Konvensional satu-satunya di daerah Sulawesi Tengah yang menerapkan sistem bagi Hasil pada usaha simpan panjamnya yang mempunyai misi membangun perekonomian masyarakat pada umumnya dan anggota pada khususnya di Desa Bunobogu.

Koperasi Serba Usaha (KSU) Amanah adalah Koperasi dengan jumlah anggota 250 orang yang memiliki asset dan sisa hasil usaha yang terus meningkat dari tahun ke tahun, sejak berdirinya pada tahun 2003 sampa sekarang. Permasalahan di Koperasi Serba Usaha (KSU) Amanah Desa Bunobogu dalam bentuk sistem bagi hasil dimana angsuran porsi yang telah di sepakati selalu menunggak dan pemantauan yang kurang terhadap manajemen usaha yang didirikan oleh anggota dapat mengakibatkan adanya pengecilan profit dari keuntungan yang berpengaruh pada pembagian porsi bagi hasil. Usaha yang didirikan anggota kebanyakan tergolong usaha kecil menengah jadi sering di temui usaha tanpa pembukuan yang tidak jelas dan hanya membuat pembukuan anggaran yang asal-asalan. Namun demikian, tak menjadi alaasan untuk menghambat pertumbuhan koperasi yang tiap tahunnya mengalami peningkatan. Di buktikan dalam tabel data perkembangan koperasi Amanah yang tiap tahunnya terus meningkat sebagai berikut:

\section{Perkembangan Koperasi Serba Usaha (KSU) Amanah}

\begin{tabular}{|l|l|l|l|c|}
\hline NO & Tahun & \multicolumn{1}{|c|}{ Aset koperasi } & Sisa Hasil Usaha & $\begin{array}{l}\text { Kantor dan } \\
\text { Perlengkapannya }\end{array}$ \\
\hline 1 & 2004 & $\mathrm{Rp} .52 .120 .482$ & $\mathrm{Rp} .9 .245 .112$ & Pinjam \\
\hline 2 & 2005 & $\mathrm{Rp} .63 .414 .570$ & $\mathrm{Rp} .10 .835 .372$ & Pinjam \\
\hline 3 & 2006 & $\mathrm{Rp} .126 .318 .866$ & $\mathrm{Rp} .11 .104 .000$ & Pinjam \\
\hline 4 & 2007 & $\mathrm{Rp} .286 .427 .433$ & $\mathrm{Rp} .21 .058 .784$ & Pinjam \\
\hline 5 & 2008 & $\mathrm{Rp} .388 .217 .723$ & $\mathrm{Rp} .32 .349 .322$ & Milik sendiri \\
\hline 6 & 2009 & $\mathrm{Rp} .590 .574 .835$ & $\mathrm{Rp} .38 .226 .404$ & Milik sendiri \\
\hline 7 & 2010 & $\mathrm{RP} .827 .721 .888$ & $\mathrm{Rp} .43 .387 .653$ & Milik sendiri \\
\hline 8 & 2011 & $\mathrm{Rp} .1 .025 .879 .653$ & $\mathrm{Rp} .67 .642 .530$ & Milik sendiri \\
\hline 9 & 2012 & $\mathrm{Rp} .1 .365 .773 .914$ & $\mathrm{Rp} .86 .475 .687$ & Milik sendiri \\
\hline 10 & 2013 & $\mathrm{Rp} .1 .667 .601 .753$ & $\mathrm{Rp} .110 .475 .204$ & \\
\hline 11 & 2014 & $\mathrm{Rp} .1 .977 .643 .791$ & $\mathrm{Rp} .121 .336 .646$ & siki \\
\hline
\end{tabular}

Sumber: Koperasi Serba Usaha (KSU) Amanah Desa Bunobogu

Berdasarkan data di atas ternyata sistem bagi hasil yang di terapkan oleh Koperasi Serba Usaha (KSU) Amanah sangat berpengaruh pada pertumbuhan koperasi dan kesejahteraan anggota. Berdasarkan uraian diatas, maka penulis mengangkat permasalahan tentang implementasi sistem bagi hasil Mudharabah pada Koperasi Serba Usaha (KSU) Amanah Desa Bunobogu Kecamatan Bunobogu, Kab. Buol, selain itu 
penulis juga membahas tentang Kendala apa yang di hadapi Koperasi Serba Usaha (KSU) Amanah Desa Bunobogu dalam penerapan sistem bagi hasil mudharabah dan bagaimana penyelesaiannya?

\section{B. Landasan Teori}

\section{a. Koperasi}

Pada hakekatnya koperasi merupakan suatu lembaga ekonomi yang sangat diperlukan dan penting untuk dipertahankan, koperasi merupakan suatu alat bagi orangorang yang ingin meningkatkan taraf hidupnya. Dasar kegiatan koperasi adalah kerjasama yang dianggap sebagai suatu cara untuk memecahkan berbagai masalah atau persoalan yang dihadapi oleh masing-masing masyarakat khususnya untuk kalangan ekonomi yang lemah. Koperasi lahir pada permulaan abad ke-19, sebagai reaksi terhadap sistem liberialisme ekonomi, yang pada waktu itu segolongan kecil pemilik-pemilik modal menguasai kehidupan masyarakat. Kata koperasi berasal dari bahasa latin coopere yang dalam bahasa Inggris disebut cooperation dan cooperative.

Koperasi berasal dari kata co dan operation yang mengandung arti bekerja sama untuk mencapai tujuan. Kerjasama adalah adanya dua orang atau lebih yang bekerja bersama-sama untuk mencapai satu atau beberapa tujuan. Dengan demikian dapat disimpulkan bahwa koperasi adalah suatu bentuk kerja sama dalam waktu yang relatif lama. Sistem pemikirian esensialis-nominal yang dikemukakan oleh Hanel pada tahun 1989. Dalam hal ini Hanel mengemukakan bahwa ada dua pendekatan dalam mendefinisikan koperasi baik dalam teori maupun praktek. Kedua pendekatan yang dimaksud yaitu, pendekatan ilmiah esensialis (pengertian koperasi menurut hukum) dan kedua, pendekatan ilmiah nominalis (pengertian koperasi menurut ekonomi). Pendekatan imiah esensial (legal sense) adalah suatu pendekatan dalam mendefinisikan koperasi selalu bertitik tolak dari prinsip-prinsip koperasi, terutama prinsip-prinsip koperasi yang diterapkan oleh para pelopor koperasi.

Pedekatan esensialis beranggapan bahwa prinsip-prinsip koperasi di satu pihak memuat sejumlah nilai, norma, dan tujuan konkrit yang harus ditemukan pada semua koperasi. Di pihak lain, prinsip-prinsip tersebut merupakan prinsip-prinsip pengembangan organisasi dan pedoman-pedoman kerja yang pragmatis, yang hanya berhasil diterapkan pada keadaan-keadaan tertentu. Pengertian atau definisi koperasi menurut pendekatan ilmiah esensial : menurut Undang-Undang Nomor 25 Tahun 
1992 tentang perkoperasian menyatakan bahwa koperasi adalah badan usaha yang beranggotakan orang seorang atau badan hukum koperasi dengan melandaskan kegiatannya berdasarkan prinsip koperasi sekaligus sebagai gerakan ekonomi rakyat yang berdasar atas asas kekeluargaan; ayat (2) Perkoperasian adalah segala sesuatu yang menyangkut kehidupan koperasi; ayat (3) Koperasi Primer adalah Koperasi yang didirikan oleh dan beranggotakan orang seorang; ayat (4) Koperasi Sekunder adalah Koperasi yang didirikan oleh dan beranggotakan Koperasi; ayat (5) Gerakan Koperasi adalah keseluruhan organisasi Koperasi dan kegiatan perkoperasian yang bersifat terpadu menuju tercapainya cita-cita bersama Koperasi". 19 Berbeda dengan pendapat para esensialis, maka menurut pengertian nominalis, yang sesuai dengan pendekatan ilmiah modern dalam ilmu ekonomi koperasi, koperasi adalah lembaga-lembaga atau organisasi-organisasi yang tanpa memperhatikan bentuk hukum atau wujudnya memenuhi kriteria dibawah

1. Sejumlah individu yang bersatu dalam suatu kelompok atas dasar sekurangkurangnya satu kepentingan atau tujuan yang sama (Kelompok Koperasi)

2. Anggota-anggota kelompok koperasi secara individual bertekad mewujudkannya, yaitu memperbaiki situasi ekonomi dan sosial mereka, melalui usaha bersama dan saling tolong menolong (Swadaya dari Kelompok Koperasi)

3. Sebagai instrumen (wahana) untuk mewujudkannya adalah suatu perusahaan yang dimiliki dan dibina secara bersama (Perusahaan Koperasi)

4. Perusahaan Koperasi itu ditugaskan untuk menunjang kepentingan para anggota koperasi itu, dengan cara menyediakan atau menawarkan barang dan jasa yang dibutuhkan oleh para anggota dalam kegiatan ekonominya, yaitu dalam perusahaan atau rumah tangganya masing-masing (Tujuan/Tugas dan Promosi Anggota) Dari pengertian-pengertian tersebut koperasi merupakan organisasi ekonomi, tindakan ekonomi dalam koperasi antara lain dalam bentuk usaha untuk meningkatkan usaha koperasi itu sendiri. ${ }^{3}$

Dengan demikian sebagai organisasi ekonomi, koperasi melakukan kegiatan ekonomi melalui unit-unit usaha yang diadakannya dengan tujuan untuk memenuhi kebutuhan anggota serta untuk 20 meningkatkan taraf hidup anggota pada khususnya dan masyarakat pada umumnya, sehingga kesejahteraan yang merata bagi masyarakat

${ }^{3}$ Mohamad Iqbal, hlm. 60 
Indonesia yang kita cita-citakan dapat terwujud. Menurut Peraturan Pemerintah Nomor 9 Tahun 1995 tentang Pelaksanaan Kegiatan Usaha Simpan Pinjam, kegiatan usaha simpan pinjam adalah kegiatan yang dilakukan untuk menghimpun dana dan menyalurkan kembali dana tersebut melalui usaha simpan pinjam dari dan untuk anggota koperasi yang bersangkutan, calon anggota koperasi yang bersangkutan, koperasi yang bersangkutan, koperasi lain atau anggotanya. Sebagai sebuah lembaga keuangan non bank, koperasi adalah suatu usaha yang dimiliki dan diawasi oleh pengguna jasanya serta membagikan keuntungan (manfaat ekonomi) yang diperoleh dari kegiatan bisnis berdasarkan tingkat partisipasi anggotanya. Menurut UndangUndang Nomor 25 Tahun 1992 tentang fungsi, peran dan prinsip koperasi diatur dalam Bab III Pasal 4 dijelaskan bahwa fungsi dan peran koperasi adalah sebagai berikut :

1. Membangun dan mengembangkan potensi dan kemampuan ekonomi anggota pada khususnya dan masyarakat pada umumnya untuk meningkatkan kesejahteraan ekonomi dan sosial mereka.

2. Turut serta secara aktif dalam upaya mempertinggi kualitas kehidupan manusia dan masyarakat.

3. Memperkokoh perekonomian rakyat sebagai dasar kekuatan dan ketahanan perekonomian nasional dengan Koperasi sebagai soko gurunya. 21

4. Berusaha untuk mewujudkan dan mengembangkan perekonomian nasional, yang merupakan usaha bersama berdasar atas asas kekeluargaan dan demokrasi ekonomi. $^{4}$

Dari pengertian koperasi tersebut dapat dikemukakan tiga konsep operasional koperasi sebagai berikut :

\section{Prinsip kepemilikan}

Koperasi dimiliki oleh anggota yang mendanai dan sekaligus menggunakan jasa koperasi itu.

\section{Prinsip kontrol (pengawasan)}

Koperasi dalam menjalankan kegiatan bisnisnya diawasi oleh para anggotanya sendiri yang bukan hanya berkedudukan sebagai pemilik melainkan juga sebagai pengguna jasa koperasi itu.

3. Prinsip pembagian keuntungan

${ }^{4}$ Ibid. 98 
Hasil usaha koperasi dibagikan kepada para anggotanya sesuai dengan intensitas keterlibatannya dalam koperasi.Koperasi simpan pinjam adalah usaha pembiayaan yang menghimpun dana dari anggotanya yang kemudian menyalurkan kembali dana tersebut kepada anggota atau masayarakat umum. Koperasi simpan pinjam melakukan usaha penyimpanan dan peminjaman uang untuk keperluan para anggotanya. ${ }^{5}$

\section{b. Koperasi syariah}

Koperasi Syariah adalah koperasi yang prinsip kegiatan, tujuan dan kegiatan usahanya berdasarkan pada syariah Islam yaitu Al-quran dan Assunnah. Jadi mereka melakukan kegiatan usahanya berdasarkan tuntunn agama.Serta melakukan kegiatan usaha yang sesuai dengan syariat Islam. Sedangkan Pengertian umum dari Koperasi syariah adalah badan usaha koperasi yang menjalankan usahanya dengan prinsipprinsip syariah. Bukan prinsip yang lain.

Tujuan Koperasi Syariah adalah Meningkatkan kesejahteraan anggota pada khususnya dan masyarakat pada umumnya serta turut membangun tatanan perekonomian yang berkeadilan sesuai dengan prinsip-prinsip islam.

Fungsi dan Peran Koperasi Syariah

1. Membangun dan mengembangkan potensi dan kemampuan anggota pada khususnya, dan masyarakat pada umumnya, guna meningkatkan kesejahteraan sosial ekonominya;

2. Memperkuat kualitas sumber daya insani anggota, agar menjadi lebih amanah, professional (fathonah), konsisten, dan konsekuen (istiqomah) di dalam menerapkan prinsip-prinsip ekonomi islam dan prinsip-prinsip syariah islam;

3. Berusaha untuk mewujudkan dan mengembangkan perekonomian nasional yang merupakan usaha bersama berdasarkan azas kekeluargaan dan demokrasi ekonomi;

4. Sebagai mediator antara menyandang dana dengan penggunan dana, sehingga tercapai optimalisasi pemanfaatan harta;

5. Menguatkan kelompok-kelompok anggota, sehingga mampu bekerjasama melakukan kontrol terhadap koperasi secara efektif;

6. Mengembangkan dan memperluas kesempatan kerja;

7. Menumbuhkan-kembangkan usaha-usaha produktif anggota.

5 Ibid, hal. 287 
Landasan Koperasi Syariah

1. Koperasi syariah berlandaskan Pancasila dan Undang-Undang Dasar 1945.

2. Koperasi syariah berazaskan kekeluargaan.

3. Koperasi syariah berlandaskan syariah islam yaitu al-quran dan as-sunnah dengan saling tolong menolong (ta'awun) dan saling menguatkan (takaful).

Prinsip Ekonomi Islam dalam Koperasi Syariah

1. Kekayaan adalah amanah Allah swt yang tidak dapat dimiliki oleh siapapun secara mutlak.

2. Manusia diberi kebebasan bermu'amalah selama bersama dengan ketentuan syariah.

3. Manusia merupakan khalifah Allah dan pemakmur di muka bumi.

4. Menjunjung tinggi keadian serta menolak setiap bentuk ribawi dan pemusatan sumber dana ekonomi pada segelintir orang atau sekelompok orang saja.

Prinsip Syariah Islam dalam Koperasi Syariah

1. Keanggotan bersifat sukarela dan terbuka.

2. Keputusan ditetapkan secara musyawarah dan dilaksanakan secara konsisten dan konsekuen (istiqomah).

3. Pengelolaan dilakukan secara transparan dan profesional.

4. Pembagian sisa hasil usaha dilakukan secara adil, sesuai dengan besarnya jasa usaha masing-masing anggota.

5. Pemberian balas jasa modal dilakukan secara terbatas dan profesional menurut sistem bagi hasil.

6. Jujur, amanah dan mandiri.

7. Mengembangkan sumber daya manusia, sumber daya ekonomi, dan sumber daya informasi secara optimal.

8. Menjalin dan menguatkan kerjasama antar anggota, antar koperasi, serta dengan dan atau lembaga lainnya.

Usaha koperasi syariah meliputi semua kegiatan usaha yang halal, baik dan bermanfaat (thayyib) serta menguntungkan dengan sistem bagi hasil dan tanpa riba, judi atau pun ketidakjelasan (ghoro). Untuk menjalankan fungsi perannya, koperasi syariah menjalankan usaha sebagaimana tersebut dalam sertifikasi usaha koperasi. Usaha-usaha yang diselenggarakan koperasi syariah harus sesuai dengan fatwa dan ketentuan Dewan Syariah Nasional Majelis Ulama Indonesia. Usaha-usaha yang 
diselenggarakan koperasi syariah harus tidak bertentangan dengan peraturan perundang-undangan yang berlaku.

Membentuk koperasi memang diperlukan keberanian dan kesamaan visi dan misi di dalam intern pendiri. Selain itu, mendirikan koperasi syariah memerlukan perencanaan yang cukup bagus agar tidak berhenti di tengah jalan. Adapun agar diakui keabsahannya, hendaklah koperasi syariah disahkan oleh notaris. Untuk mendirikan koperasi syariah, kita perlu memiliki modal awal. Modal Awal koperasi bersumber dari dana usaha. Dana-dana ini dapat bersumber dari dan diusahakan oleh koperasi syariah, misalkan dari Modal Sendiri, Modal Penyertaan dan Dana Amanah. Modal Sendiri didapat dari simpanan pokok, simpanan wajib, cadangan, Hibah, dan Donasi, sedangkan Modal Penyerta didapat dari Anggota, koperasi lain, bank, penerbitan obligasi dan surat utang serta sumber lainnya yang sah. Adapun Dana Amanah dapat berupa simpanan sukarela anggota, dana amanah perorangan atau lembaga.

\section{Metode Penelitian}

Penulis mengunakan metode penelitian Deskriptif Kualitatif, yaitu dengan mencocokkan antara realita dengan teori yang berlaku dengan menggunakan metode deskriptif. Penelitian dengan metode deskriptif di lakukan karena peneliti ingin menjawab persoalan-persoalan tentang fenomena yang ada/berlaku sekarang ${ }^{6}$. Penelitian ini merupakan upaya untuk mendeskripsikan bagaimana implementasi sistem bagi hasil pada koperasi. Adapun pendekatan yang saya gunakan adalah pendekatan sosiologis, psikologis dan sumber data adalah primer dan sekunder

\section{Hasil dan Pembahasan}

\section{a. Hasil Penelitian}

Usaha yang berjalan di Koperasi Serba Usaha (KSU) Amanah Desa Bunobogu adalah unit foto copy/ATK UKM Mart dan Unit Simpan Pinjam (UST) dengan jumlah, masa angsuran ditetapkan dalam keputusan Rapat Anggota Tahunan (RAT)

${ }^{6}$ Ine I. Amirman. Yousda dan Zainal Arifin, Penelitian dan statistic pendidikan, (Bandung: Bumi Aksara). H.21 
Kepercayaan angota pada KSU Amanah Desa Bunobogu semakin meningkat dan berkembang setiap tehunnya seperti yang terlihat bahwa sampai akhir tahun buku 2014 aset yang diperoleh KSU Amanah meningkat sebesar 18,5\%.

Perkembangan Aset Selama 5 Tahun

\begin{tabular}{|l|l|}
\hline \multicolumn{1}{|c|}{ Tahun } & \multicolumn{1}{c|}{ Aset } \\
\hline 2010 & $\operatorname{Rp~827.721.888}$ \\
\hline 2011 & $\operatorname{Rp~1.025.897.653}$ \\
\hline 2012 & $\operatorname{Rp~1.365.773.914}$ \\
\hline 2013 & $\operatorname{Rp~1.667.601.753~}$ \\
\hline 2014 & $\operatorname{Rp~1.977.643.791}$ \\
\hline
\end{tabular}

Sumber : Laporan Tahunan Tahun Buku 2014

Pada sisi secara lebih efeekti dengan memperhatikan kelayakan usaha, serta pemakaiyan konsep Sariah dalam transaksi. Penyelesaian bermaslah selama ini dilakukan dengan prosedur dan ketentuan syariah dengan tidak meninggalkan prinsip kekeluargaan sesuai dengan prinsip dasar koperasi. Pembiayaan yang terealisasi pada tahun buku 2014 tecatat mengalami peningkatan sebesar 4,01\%

Perkembangan Pembiayaan Selama 5 Tahun

\begin{tabular}{|c|c|}
\hline Tahun & Pembiayaan \\
\hline 2010 & $\operatorname{Rp~9.286.553~}$ \\
\hline 2011 & $\operatorname{Rp} 9.571 .254$ \\
\hline 2012 & $\operatorname{Rp} 9.811 .215$ \\
\hline 2013 & $\operatorname{Rp~10.223.112~}$ \\
\hline 2014 & $\operatorname{Rp~10.633.665~}$ \\
\hline
\end{tabular}

Sumber : Laporan Tahunan Tahun Buku 2014

Dari pembiayaan Sisa Hasil Usaha (SHU) mengalami peningkatan sebesar 9,8\%

Sisa Hasil Usaha (SHU) Selama 5 Tahun

\begin{tabular}{|c|c|}
\hline Tahun & SHU \\
\hline 2010 & $\operatorname{Rp~43.387.653~}$ \\
\hline 2011 & $\operatorname{Rp~67.642.530~}$ \\
\hline 2012 & $\operatorname{Rp~86.475.687}$ \\
\hline 2013 & $\operatorname{Rp~110.475.204~}$ \\
\hline 2014 & $\operatorname{Rp~121.336.646~}$ \\
\hline
\end{tabular}

Sumber : Laporan Tahunan Tahun Buku 2014 
Dari perkembagan kegiatan usaha Koperasi Serba Usaha (KSU) Amanah Desa Bunobogu Telah mengalami kemajuan yang sangat signifikan sehingganya dapat membangun serta menempati gedung baru yang kelak nanti dapat diharapkan akan semakin menambah kepercayaan anggota dan masyarakat dalam meningkatkan serta mengembangkan KSU Amanah kedepan.

Peran anggota dalam menggembangkan KSU Amanah Desa Bunobogu sengat besar, semakin anggota aktif dalam pembiayaan di KSU Amanah desa Bunobogu semakin kuat pula keuangan yang ada daam tubuh koperasi. KSU Amanah Desa Bunobogu mempunyai kebijakan untuk membayar simpanan wajib bersamaan dengan pembayaran angsuran pembiayaan. Kebijakan ini dilakukan untuk tetap menjaga rasio kecupan modal. ${ }^{7}$

Implementasi sistem bagi hasil di KSU Amanah Betujuan untuk meringankan masyarakt pada umunya dan anggota pada khususnya dalam melakukan pinjamana agar terhidar dari rentenir dan bunga yang berlebihan.

Sistem bagi hasil didasarkan pada kesepakatan awal. Kesepakatan awal tersebut untuk megetahui porsi (Nisbah) antara pihak koperasi dengan anggota dalam pembagian keuntungan usaha yang akan dikelolah oleh anggota. Kesepakatan dilakukan secara transparan dan penuh kehati-hatian, pihak koperasi juga harus mengetahuai profil anggota yang meminjam dengan memahami kekuatan finansial yang dimiliki. Koperasi tidak akan mengeluarkan pinjaman melebihi kekuatan finansial anggota yang meminjam karena akan berdampak pada angsuran besar dan sangat membebani anggota. Hal ini sesuai dengan pernyataan yang dikemukakan oleh ibu Dian Eka Putri S.Pd selaku sekretaris KSU Amanah Desa Bunobogu.

"pada saat akad kita langsung menentukan porsi pembagian atau nisbah keuntungan yang di tetapkan di Koperasi Serba Usaha (KSU) Amanah itu 50:50 . dan juga, sebelumnya di lakukan survey karena tidak semua permintaan bias di penuhi, tapi sesuai dengan dengan kemampuan dengan adanya wawancara, misalnya anggota mempunyai kewajiban tiap bulannya yaitu diatas Rp.1.500.000, dari situlah bias dipelajari bahwa dia mempunyai Rp.1.000.000 jangan di kasi Rp.2.000.000 nanti dalam proses akan mengalami kemacetan". ${ }^{\circ}$

\footnotetext{
${ }^{7}$ Suwandi, Ketua Koperasi serba Usaha (KSU) Amanah Desa Bunobogu, Wawancara, Tanggal 05 Agustus 2015.

${ }^{8}$ Dian Eka Putri, Sekretaris Koperasi Serba Usaha (KSU) Amanah, wawancara tanggal 05 agustus 2015
} 
Jika dalam usahanya mengalami kerugian maka kerugian tersebut di tanggung bersama atau melakukan pembiayaan awal untuk memulai usaha baru atau melanjutkan usaha yang teah di kelola sebelumnya dengan di damping oleh pihak koperasi dalam pengelolaan usaha yang telah di dirikan agar nantinya tidak terjadi kerugian lagi dalam usahanya. Hal ini sesuai dengan pernyataan yang di kemukakan oleh Irvan Sahari selaku manajer yang memberikan pernyataan sebagai berikut:

:jika usahanya terjadi kerugian sedini mungkin dari pihak pengelola memantau, misalnya bulan ini tidak mengangsur, harus segera di tindak lanjuti, kenapa tidak mengangsur? Mungkin seminggu lagi, kalau sampai berlarut-larut ini harus segera di tindak lanjuti. Mungkin ada manajemen yang keliru, akhirnya kita upayakan jemput bola". 9

Saling menguntungkan itulah kelebihan dari sistem bagi hasil, besarnya bagi hasil di Koperasi Serba Usaha (KSU) Amanah Desa Bunobogu.

Mudharabah adalah akad kerja sama usaha perniagaan antara pihak pemilik dana (shahibul maal) sebagai pihak yang menyediakan modal dana sebesar $100 \%$ dengan pihak pengelola modal (mudharib), untuk di usahakan dengan porsi (nisbah) keuntungan akan di bagi bersama sesuai dengan kesepakatan di muka dari kedua belah pihak, sedangkan kerugian (jika ada) akan di tanggung pemilik modal, kecuali jika di temukan adanya kelalaian atau kesalahan oleh pihak pengelola dana (mudharib), seperti penyelewengan, kecurangan, dan penyalahgunaan dana. ${ }^{10}$

Proses pembiayaan mudharabah sangat singkat akan tetapi menekankan pada pemahaman dalam kesepakatan agar tidak terjadi miss komunikasi dan kejelasan anggota sebagai pengelola untuk mendirikan usaha yang di geluti.

Contoh perhitungan sederhana pola pembiayaan bagi hasil mudharabah yang di tetapkan di Koperasi Serba Usaha (KSU) Amanah Desa Bunobogu yang di ambil dari pengamatan. Bapak Samsul adalah anggota KSU Amanah yang membutuhkan modal untuk usahanya. Pihak koperasi meminjamkan Rp.10.000.000 dengan kesepakan nisbah $50 \%$ untuk koperasi dan 50\% untuk peminjam dengan angsuran 5\% untuk peminjaman modalnya setiap bulan. Jika keuntungan yang di dapat 1 bulan Rp.500.000 maka bapak Samsul dalam membayar angsuran kepada koperasi adalah:

Rp. $10.000 .000 \times 2 \%=$ Rp. 200.000

${ }^{9}$ Irvan Sahari, Manajer KSU Amanah, wawancara, tanggal 05 Agustus 2015

${ }^{10}$ Juklak Koperasi Jasa Keuangan Syariah (KJKS) Mentri Negara Koperasi dan UKM 2004. H.21 
Rp.500.000 x 50\% = Rp. 250.000

Simpanan wajib $\quad=$ Rp. 10.000

Jumlah $\quad=$ Rp.460.000

Jadi, bapak Samsul membayar angsuran Rp. 460.000 dengan keuntungan di dapat dalam porsi 50\% dengan perhitungan (Rp.500.000 x 50\%) sebesar Rp. 250.000

Dalam implementasi bagi hasil terdapat kendala yang di hadapi, sebagaimana yang di utarakan oleh Bapak Irvan Sahari selaku manajer yang memberikan pernyataan sebagai berikut:

"kalau operasionalnya tergantung pengelolanya, setiap hari akan mengalami pemantauan, kalau biaya operasionalnya bengkak, berarti harus di tekan, yang termasuk kenadala juga adalah SDM dari anggota, kita harus maklum. Sifat anggota beragam, ada yang mengerti, da nada yang tidak mengerti, da nada yang pura-pura mengerti, itu tugas saya agar anggota mengerti dengan menjelaskan dengan bahasa yang mudah di pahami anggota jangan sampai ada keraguan, anggota masih belum mengerti kalau seperti kami tidak berani mengeluarkan pembiayaan". 11

Keterangan tersebut mempunyai arti pembiayaan menggunakan bagi hasil selalu di pantau terus. Kendala yang di hadapi SDM dari anggota yang terbatas jadi terkadang perlu beberapa kali menjelaskan agar anggota paham, hal ini sering terjadi saat proses kesepakatan.

Dari kendala yang sudah di paparkan, pihak Koperasi Serba Usaha (KSU) Amanah Desa Bunobogu mempunyai cara tersendiri untuk mengatasinya. Salah satunya yang di kemukakan oleh Bapak Irvan Sahari yang memberikan pernyataan sebagai berikut:

"kita melakukan pembinaan terhadap anggota agar mengerti tentang sistem bagi hasil walaupun hanya bisa memberikan pemahaman sedikit, kita juga melakukan pendampingan langsung dalam usaha". ${ }^{12}$

Keterangan tersebut mengandung arti bahwa dalam mengatasi kendala pelaksanaan sistem bagi hasil perlu melakukan pembinaan aggota agar mengerti dengan cara bertahap. Pihak koperasi juga biasa melakukan pendampingan langsung dalam usaha agar laba yang di peroleh dapat di lihat secara jelas rinciannya.

\footnotetext{
${ }^{11}$ Irvan Sahari, Manajer KSU Amanah, wawancara, tanggal 05 Agustus 2015

${ }^{12}$ ibid
} 


\section{b. Pembahasan hasil penelitian}

Dalam implementasi sistem bagi hasil mudharabah hal yang terpenting adalah hasil kesepakatan antara pihak koperasi antara pihak koperasi (Shohibul maal) dan anggota (Mudharib). Di KSU Amanah Desa Bunobogu kesepakatan di lakukan dengan transparan dari pihak koperasi menjelaskan tentang bagi hasil terhadap anggota yang ingin meminjam modal agar saat usaha yang di geluti sudah jalan tidak ada kerancuan dalam pembagian keuntungan yang sebelumnya telah di sepakati bersama. Dalam proses kesepakatan (akad) yang terjadi di KSU Amanah Desa Bunobogu meliputi:

1. Penentuan porsi bagi hasil untuk koperasi dan anggota

2. Pihak koperasi tidak menanggung resiko jika terjad kelalaian yang di lakukan oleh anggota dalam menjalankan usahanya.

3. Ada bukti tertulis menandakan sah bahwa telah terjadi kesepakatan pola pembiayaan bagi hasil mudharabah di sertai penyerahan jaminan kepada pihak koperasi.

Implementasi sistem bagi hasil mudharabah di KSU Amanah Desa Bunobogu menggunakan jaminan dalam setiap proses kesepakatan, hal ini mengacu pada peraturan DSN MUI No. 07/DSN-MUI/IV/2000 tentang mudharabah, menyatakan bahwa pembiayaan bagi hasil mudharabah tidak di wajibkan untuk menggunakan jaminan akan tetapi di perbolehkan untuk menghindari penyimpangan yang di lakukan oleh anggota.

Dalam pembiayaan mudharabah di KSU Amanah Desa Bunobogu jika dalam pengelolaan usaha terdapat kerugian sepenuhnya akan di tanggung oleh pihak koperasi (Shahibul maal). Koperasi bias saja mengambil alih pengelolaan usaha yang telah di dirikan oleh anggota atau koperasi melakukan pendampingan secara langsung terhadap usaha yang sudah ada dan akan memberikan pengelolaan secara penuh kembali kepada anggota jika usahanya sudah menghasilkan laba yang sudah mencukupi.

Usaha yang di geluti oleh anggota sebagaian besar tergolong usaha kecil dan menengah, hal itu membuat anggota beranggapan tidak perlu melakukan pembukuan anggaran secara mendetail. Pembukuan anggaran yang asal-asalan dapat memberikan kesempatan pada anggota untuk berbuat curang dengan membuat pembukuan palsu dengan merendahkan laba yang diperoleh agar dapat memperoleh keuntungan yang lebih banyak bagi anggota yang menjalankan usaha. 
Dari hasil pengamatan kendala-kendala yang di hadapi KSU Amanah desa Bunobogu:

1. Faktor intern

- Pelayanan pembiayaan hampir keseluruhan di serahkan kepada manajer.

- Karyawan yang terbatas menghambat pemantauan aggaran secara berkala dari usaha yang di dirikan anggota.

\section{Faktor Ekstern}

- Anggota mengabaikan pembukuan anggaran terhadap usaha yang mempersulit pemantauan laba bersih yang di dapat.

- Kesulitan dalam memonitoring usaha yang di geluti oleh anggota yang dapat mengakibatkan adanya kecurangan dari anggota dalam melaporkan keuntungan lebih rendah dari yang di dapat.

Pola pembiayaan bagi hasil di dasarkan pada kesepakatan untuk mengetahui porsi (nisbah) yang di peroleh oleh pihak koperasi maupun anggota. Bagi hasil di dapat dari hasil keuntungan yang di peroleh oleh anggota dalam menjalankan usahanya yang seterusnya akan di bagi menurut porsi yang telah di sepakati dan pembagian di lakukan setiap bulannya. Untuk mengetahui usaha yang di jalankan anggota berjalan dengan baik atau tidak, perlu adanya pemantauan secara berkala yang harus di lakukan oleh pihak koperasi agar tidak terjadi pembukuan ganda dan anggota menyampaikan keuntungan lebih rendah dari yang di peroleh sebenarnya kepada pihak koperasi KSU Amanah melakukan pemantauan selama 2 minggu bahkan 1 bulan sekali terhadap usaha yang di jalankan oleh anggota.

Dalam usaha yang di dirikan tidak seterusnya menghasilkan laba yang maksimal, anggota sering kesulitan menjalankan usahanya pada tiga bulan pertama. Pada KSU Amanah desa Bunobogu jika pihak koperasi mengetahui usaha yang di jalankan anggota mengalami kerugian maka secepatnya pihak koperasi mengambil alih manajemen usahanya. Anggota akan di bantu oleh pihak koperasi dalam menjalankan usahanya sampai mendapatkan laba yang maksimal, setelah tercapai laba maksimal pihak koperasi akan memberikan kembali keleluasan anggota untuk mengembangkan usahanya.

Inilah cara Koperasi serba Usaha (KSU) Amanah Desa Bunobogu menyelesaikan masalah-masalah yang terjadi dalam mencapai tujuan yang telah di 
sepakati bersama. Sehingga keanggotaan dalam koperasi ini tetap terjaga dalam menjalankan usahanya yang telah berjalan.

\section{PENUTUP}

\section{Kesimpulan}

1. Sistem bagi hasil ini telah di laksanakan oleh Koperasi Serba Usaha (KSU) Amanah Desa Bunobogu dalam bentuk pembiayaan Mudharabah. Akad pembiayaan antara pihak koperasi dan anggota dalam pembagian porsi (nisbah) yang harus di sepakati kedua belah pihak mencerminkan nilai-nilai keadilan, dan tidak terdapat hal-hal yang merugikan mitra usaha. Kesepakatan (akad) hal yang paling mendasari sistem bagi hasil.

2. KSU Amanah Desa Bunobogu memberikan pinjaman kepada anggota dalam bentuk pembiayaan bagi hasil mudharabah dengan penyertaan jaminan pada proses akadnya. Jika terjadi kelalaian yang di lakukan oleh anggota yang mengakibatkan usahanya merugi maka barang yang di buat jaminan akan di sita oleh pihak koperasi.

3. Usaha yang di dirikan anggota sebagaian besar tergolong pada usaha kecil dan menengah dari hal tersebut anggota banyak mengabaikan pembukuan anggaran terhadap usaha yang di jalankannya. Pembukuan anggaran yang tidak jelas dapat berakibat pada manipulasi laba yang di lakukan oleh anggota, dengan memperendah laba yang di peroleh dan berpengaruh pada angsuran bagi hasil. Pembukuan anggaran yang asal-asalan akibat dari SDM yang tidak mengerti tentang pebukuan anggaran dan pengawasan yang kurang dari pihak koperasi.

\section{Implikasi}

1. Pihak koperasi hendaknya rutin menyelenggarakan pelatihan dan pembinaan secara meyeluruh terhadap anggota tentang pembukuan anggaran dalam bentuk sistem akuntansi untuk usaha yang di jalankan.

2. Pihak koperasi harus membantu mengendalikan usaha dengan menuntun anggota agar dapat melaksanakan manajemen dengan baik dan melakukan pembukuan anggaran usaha dengan benar, terutama pada tiga bulan awal pendirian usaha. 
3. Pihak koperasi seharusnya melakukan pengawasan secara berkala terhadap anggaran dan usaha untuk menghindari kecurangan yang di lakukan oleh anggota dengan melakukan pembukuan ganda. 


\section{DAFTAR PUSTAKA}

Firdaus, Muhamad Sutanto, Agus Edhi, Perkoperasian sejarah, teori dan praktek. (Jakarta: Ghallia Indonesia;2002)

Ine I. Amirman. Yousda dan Zainal Arifin, Penelitian dan statistic pendidikan, (Bandung: Bumi Aksara)

Lexy J Maleong, metodologi penelitian kualitatif, cet. Tiga puluh satu: (Bandung: Remaja Rosada Karya, 2013)

ninik widiyanti dan Sunindhia, Koperasi dan Perekonomian Indonesia. (Jakarta: PT. Rineka Cipta. 2000)

Nur Indriantoro dan Bambang Supono, metedologi penelitian bisnis (Yogyakarta: PFEE,2005)

Sugiyono, Metode Penelitian Kuantitatif dan Kualitatif dan R\&D, cet 20 (Bandung: Alfabeta 2014)

Irvan Sahari, Manajer KSU Amanah, wawancara, tanggal 05 Agustus 2015

Juklak Koperasi Jasa Keuangan Syariah (KJKS) Mentri Negara Koperasi dan UKM 2004. H.21

Suwandi, Ketua Koperasi serba Usaha (KSU) Amanah Desa Bunobogu, Wawancara, Tanggal 05 Agustus 2015.

Dian Eka Putri, Sekretaris Koperasi Serba Usaha (KSU) Amanah, wawancara tanggal 05 agustus 2015 